\title{
Mixoid Liposarcoma
}

\author{
Azamris, Peri Handayani, Muhammad Rifki
}

\begin{abstract}
Abstrak
Sarkoma adalah pertumbuhan maligna jaringan mesodermal (jaringan ikat, otot, tulang). Liposarkoma adalah tumor ganas atau kanker pada jaringan lemak, yang biasanya dicirikan oleh adanya diferensiasi abortif sel - sel menjadi liposit dan merupakan tipe yang paling umum dari sarkoma jaringan lunak, muncul perlahan, membesar, tanpa rasa sakit, massa submukosa nonulserasi pada usia paruh baya. Jika terdeteksi lebih dini maka angka keberhasilan pengobatan menjadi lebih baik. Wide eksisi tumor merupakan modalitas pilihan pada penatalaksanaan Liposarkoma. Diagnosis ditegakkan berdasarkan riwayat perjalanan penyakit, pemeriksaan fisik dan pemeriksaan patologi anatomi. Dilaporkan satu kasus laki-laki berusia 74 tahun dengan diagnosis Miksoid Liposarkoma dilakukan Wide Eksisi Tumor tanpa pemberian Neo Adjuvan Terapi terlebih dahulu menunjukan perbaikan yang cukup signifikan
\end{abstract}

Kata kunci: Sarkoma, Miksoid Liposarkoma, Wide Eksisi Tumor, Neo Adjuvan Terapi

\begin{abstract}
Sarcoma is the growth of malignancy mesodermal tissue (connective tissue, muscle, bone). Liposarcoma is malignant tumor or cancer at fatty tissue, characterized by abortif differentiated cells to lipocyte and the common type of soft tissue sarcoma, appearing slowly, enlarged, painless, nonulceratif mass submucosal at the middle age. If the early detected the cure rate can be better. Wide Excision Tumor is the modality for treatment of Liposarcoma. The clinical diagnosis is made based on history of illness, physical examination and anatomical pathology examination. Reported One case, man 74 year old, diagnosed with Mixoid Liposarcoma treated by Wide Excision Tumor without given Neo Adjuvan Theraphy before showed a significant improvement.
\end{abstract}

Keywords: Sarcoma, Mixoid Liposarcoma, Wide Eksisi Tumor, Neo Adjuvan Theraphy.

Affiliasi penulis : Muhammad Rifki

Korespondensi : rifki_dr@yahoo.com Telp: 08126708060

\section{PENDAHULUAN}

Liposarkoma adalah keganasan sel-sel lemak matur dalam ruang jaringan ikat ${ }^{1}$. Liposarkoma merupakan tipe yang paling umum dari sarkoma jaringan lunak, muncul perlahan, membesar, tanpa rasa sakit, massa submukosa non ulserasi pada orang paruh baya, beberapa lesi tumbuh pesat dan menjadi ulserasi awal ${ }^{1,3}$.

\section{Epidemiologi}

Liposarkoma merupakan tumor ganas yang jarang ditemukan ${ }^{2}$. Insiden Liposarkoma pada usia 50-70 tahun. Insiden anak (5\%) dan dewasa (20\%) dari seluruh sarkoma jaringan lunak. Jumlah kasus sarkoma jaringan lunak yaitu 2,5 kasus/juta penduduk, liposarkoma sebanyak 7\%. Sering mengenai ekstremitas bawah, kepala dan leher (biasanya leher dan pipi) ${ }^{2,3}$.

Etiologi

Etiologi pasti tidak diketahui, kemungkinan melibatkan mesenkim. Tidak ada faktor lingkungan spesifik diidentifikasi ${ }^{3,4}$.
Klasifikasi

Distribusi terbagi tiga subtipe biologi yaitu ${ }^{5,6}$ :

Liposarkoma berdiferensiasi (atipikal) dan liposarkoma terdiferensiasi (liposarcoma berdiferensiasi baik sampai batas tumor yang lebih sulit dibedakan). Dengan Kecenderungan mengadakan agresi lokalinvasif, Tidak mengadakan metastase jauh, Lokasi: trunkus dan retroperitoneal, Ukurannya bisa sangat besar, Klasifikasi: Tipe adiposit menyerupai lipoma, tipe sklerosing dan tipe inflamasi, dekade tiga dan empat.

Liposarkoma mixoid/ liposarkoma sel bulat Berjumlah $40 \%$ dari semua jenis liposarkoma. Makroskopik: tumor sangat besar, Histologi terdiri: sel uniform, sel mesenkim nonlipogenik primitif bulat/oval dengan berbagai jumlah cincin signet lipoblas, dalam stroma miksoid yang prominen. Cabang pembuluh darah seperti gambaran "chicken wire" umum ditemukan. Terjadi ekstremitas, biasanya di daerah proksimal.

Liposarkoma pleomorfik; Sangat malignant berisi pleomorfik lipoblas.Aktifitas mitosis sangat tinggi, perdarahan dan nekrosis sering terjadi Jumlah pleomorfik liposarkoma lebih rendah dari $5 \%$ dari semua liposarkoma dan umumnya usia lebih tua, Lokasi: pada jaringan lunak dalam ekstremitas. Metastasis dini paru. Pada tumor ini kemungkinan hidup 5 tahunnya hanya $20-30 \%$ saja. 
Manifestasi klinis ${ }^{3,7}$, Pasien dapat melaporkan hal-hal berupa Teraba massa yang semakin membesar, Penurunan fungsi (motorik dan sensorik), Kesemutan, Pembesaran pembuluh darah, Kelelahan.

Diagnosis $^{3,4}$ ditegakkan dari Anamnesis berupa Benjolan abnormal yang semakin membesar tanpa radang dan nyeri, Penurunan berat badan. Pemeriksaan Fisik; Dinilai massa tekan, nyeri tekan, konsistensi, permukaan, ukuran, hiperemis , tanda radang. Pemeriksaan Penunjang ${ }^{7}$ berupa CT-scan MRI, Ultrasonografi dan Biopsi. Diagnosis banding ${ }^{2,5}$ berupa lipoma dan Neurofibromatosis. Penatalaksanaan $^{2,4}$ dapat Eksisi lokal luas, Radioterapi, Kemoterapi. Prognosis ${ }^{8,9}$ Kelangsungan hidup dan kontrol lokal dikaitkan dengan subtipe tumor, tingkat ketahanan hidup 5 tahun untuk liposarkoma adalah; liposarkoma differensiasi baik $85-100 \%$, myxoid liposarkoma 77-95\%, liposarkoma pleomorfik $21-45 \%$, liposarkoma sel bulat $13-55 \%$.

\section{LAPORAN KASUS}

Seorang laki- laki berumur 74 tahun datang berobat ke polikilinik Bedah RSUP DR. M..Djamil Padang dengan keluhan benjolan di lengan kanan sejak \pm 10 tahun yang lalu. Awalnya benjolan terasa kecil makin lama makin membesar. Benjolan terasa berat sudah dirasakan mengganggu aktifitas seharihari. Pasien tidak bisa mendekatkan lengan ke badan sehingga posisi lengan pasien seperti orang mengangkat beban. Rasa nyeri disangkal pasien dan riwayat trauma sebelumnya tidak ada.

Pada pemeriksaan fisik tampak pasien sakit sedang dengan benjolan yang besar di medial humerus dekstra dengan ukuran $30 \times 20 \times 10 \mathrm{~cm}$ mendorong humerus ke arah lateral. Pada perabaan teraba massa padat kenyal dengan permukaan licin tanpa ada tanda- tanda radang dan nyeri saat ditekan. Tidak ditemukan benjolan di tempat lain.

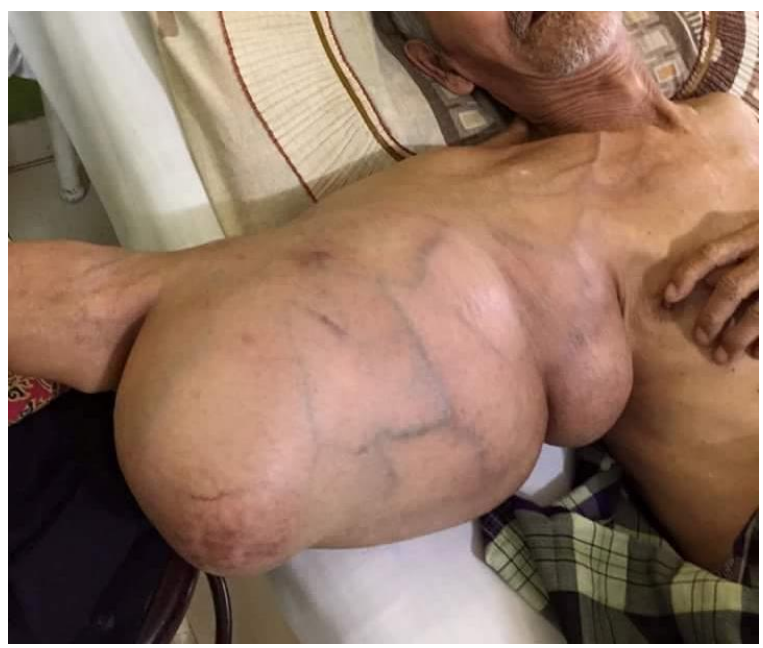

Gambar 1. Foto sebelum operasi

Pada pemeriksaan secara radiologi; foto Rontgen humerus tampak gambaran radioopaque di medial os. Humerus dengan batas tulang yang jelas, tidak terdapat gambaran osteolitik.

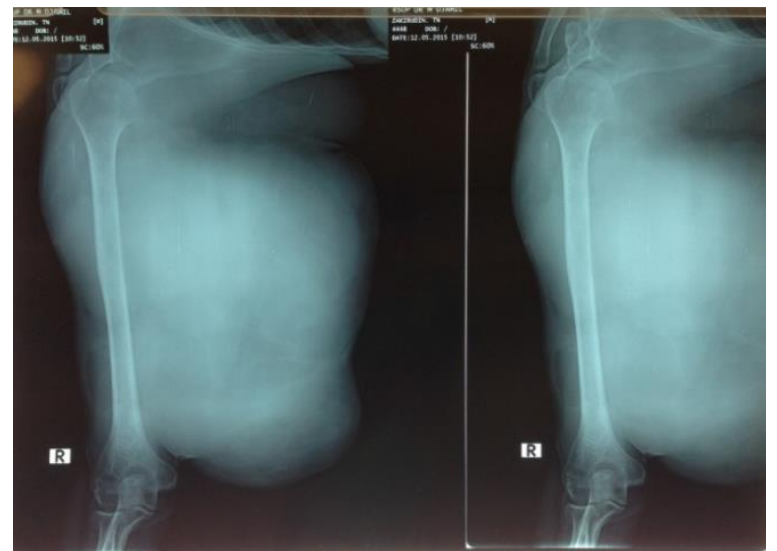

Gambar 2. Foto Rontgen Humerus Dextra

Pada pasien dilakukan tindakan bedah berupa wide eksisi, massa tumor yang diangkat $\pm 10 \mathrm{~kg}$ dengan lama operasi \pm 5 jam. Keadaan pasien setelah dilakukan wide eksisi menunjukkan perbaikan yang signifikan. Kemudian dilakukan fsioterapi untuk mengoptimalkan fungsi dari lengan kanan pasien.

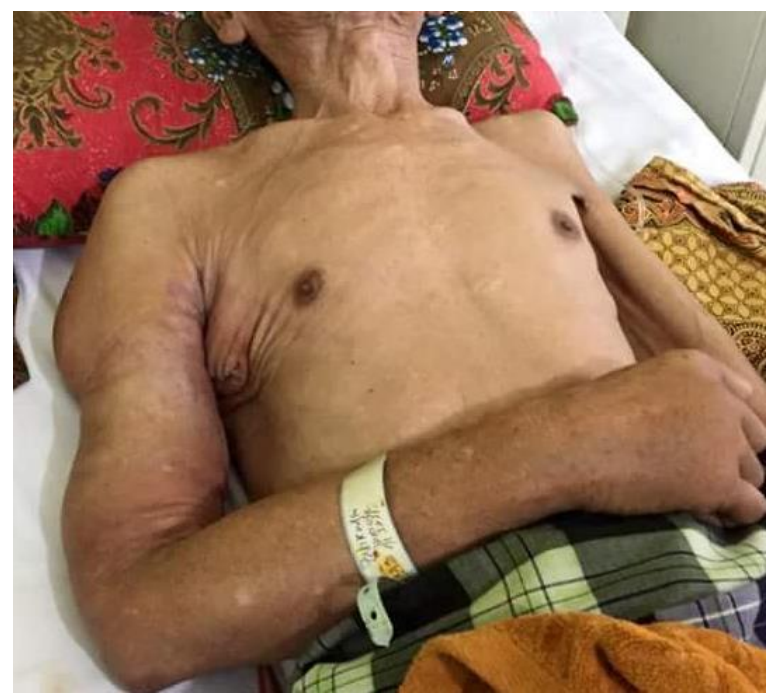

Gambar 3. Foto setelah operasi

Hasil eksisi dari tumor dengan berat $\pm 10 \mathrm{~kg}$, diperiksa ke Laboratorium Patologi Anatomi RSUP. Dr.M Djamil Padang dengan hasil suatu Mixoid Liposarcoma.

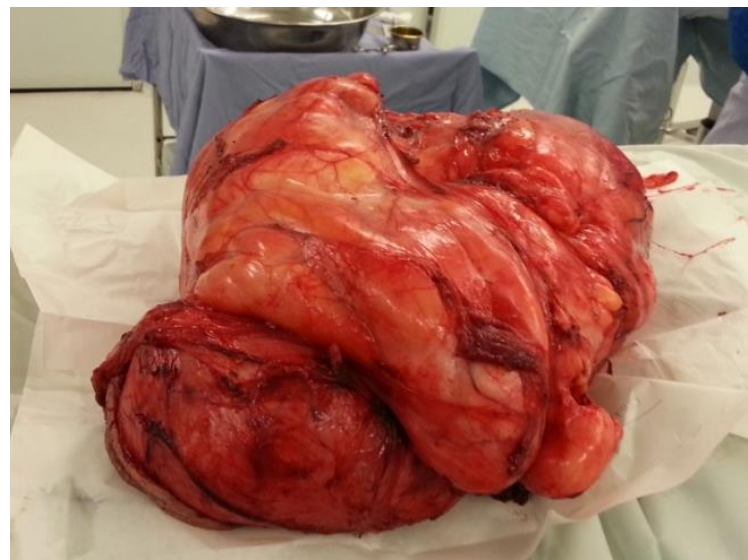

Gambar 4. Massa tumor 
Pada pemeriksaan Histopatologi tampak jaringan mixoid dengan sel chicken wire dan sel lipoblast, Gambaran ini menunjukan bahwa massa tumor merupakan suatu Mixoid Liposarcoma.

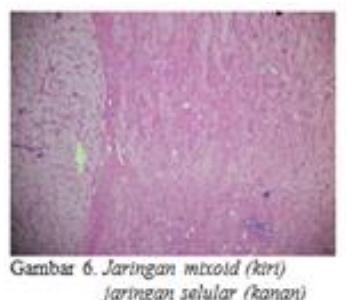
faringan seiular (kanat)

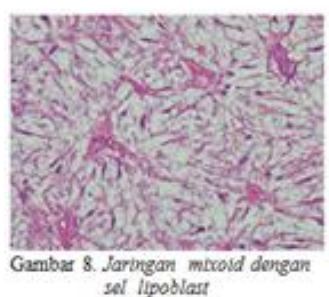
2el tipodiant

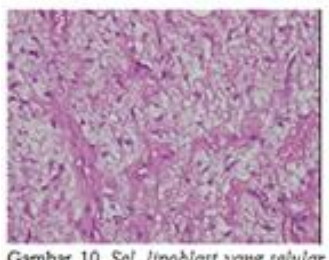

Gamber 10 Sel tipobiat jang setwlent

Gambar 6. Histopatologi

\section{Diskusi}

Sarkoma adalah pertumbuhan maligna jaringan mesodermal (jaringan ikat, otot, tulang) (Hinscliff,1999: 192). Liposarkoma adalah tumor ganas atau kanker pada jaringan lemak, yang biasanya dicirikan oleh adanya diferensiasi abortif sel-sel menjadi liposit (Behrman, 1992: 30). Liposarkoma merupakan tipe yang paling umum dari sarkoma jaringan lunak, muncul perlahan, membesar, tanpa rasa sakit, massa submukosa nonulserasi pada orang paruh baya, beberapa lesi tumbuh pesat dan menjadi ulserasi awal $^{1,2}$.

Liposarkoma merupakan tumor ganas yang jarang ditemukan ${ }^{4}$, Dari literatur sering mengenai ekstremitas bawah, namun pada kasus ini ditemukan pada ekstremitas atas ${ }^{4}$. Patogenesis dari penyakit ini belum diketahui walaupun tumor ini timbul sebagai akibat dari proses reaktif atau dysplasia ${ }^{2,4}$. Namun pernah juga dilaporkan bahwa tumor ini dapat terjadi sebagai akibat dari trauma pada daerah lesi ${ }^{3}$. Pada pasien ini tidak didapatkan riwayat trauma pada daerah lesi.

Pada pemeriksaan fisik tampak massa dengan ukuran $30 \times 20 \times 10 \mathrm{~cm}$ yang mengakibatkan tangan sulit untuk digerakan dan pasien juga sering mengeluhkan rasa kebas di telapak tangan akibat penekanan nervus medianus, setelah dilakukan pengangkatan tumor rasa kebas berkurang. Pada perabaan teraba massa padat kenyal dengan permukaan licin tanpa ada tanda- tanda radang dan nyeri saat ditekan. Tidak ditemukan benjolan di tempat lain serta pada gambaran radiologis tidak tampak gambaran infiltrasi ke tulang, maka pada kasus ini tidak dilakukan biopsi walaupun untuk menentukan jinak atau ganas pada soft tissue tumor dilakukan pemeriksaan biopsi.

Penatalaksanaan kasus ini dilakukan Wide Eksisi Tumor tanpa pemberian Neo Adjuvan Theraphy terlebih dahulu untuk memperkecil ukuran massa tumor. Pasien mengalami perbaikan yang cukup signifikan namun masih diperlukan tindakan fisioterapi untuk mengoptimalkan fungsi dari lengan kanan pasien. Hasil pemeriksaan histopatologi tumor merupakan suatu Mixoid Liposarcoma, tampak adanya gambaran chicken wire dengan sel lipoblast hiperkromatik dan sel lipoblast seluler. Berdasarkan epidemiologi, 5 years survival rate tumor ini adalah 77- $95 \%{ }^{8,9}$. Keterlambatan pasien untuk berobat disebabkan karena ketidak mampuan dari segi sosial, dengan adanya BPJS kesehatan barulah pasien berobat ke Rumah Sakit dengan lama operasi \pm 5 jam.

\section{Daftar Pustaka}

1. F. Charles Brunicardi, MD, FACS. Dana K. Andersen, MD, FACS, et al. Chapter 36 Soft Tissue Sarcomas in: Schwartz's PRINCIPLES OF SURGERY. $10^{\text {th }}$ edition. McGraw-Hill. New York 2015. Page 14651490.

2. Ewing J. Neoplastic diseases: a textbook on tumors. Philadelphia: W.B. Saunders 2009; 7: 122-206.

3. Weiss SW, Goldblum JR. Enzinger and Weiss's Soft Tissue Tumors $4^{\text {th }}$ ed. 2008. Philadelphia. Mosby. Pp: 477-510.

4. Gomez AH, Gutierrez CO, Betancourt AM, Ortiz KL. Giant Liposarcoma. World Journal of Surgical Oncology 2010; 6: 115-216

5. Sioletic S, Cin PD, Fletcher CDM, Hornick JL. Well-differentiated and dedifferentiated liposarcomas with prominent myxoid sarcoma: analysis of 56 cases. Histopathology 62, 287-293.

6. Matsumoto K, Takada M, Okabe H, Ishizawa M. Foci of signal intensities different from fat in well-differentiated liposarcoma and lipoma - Correlation between MR and histological findings. Clin Imaging 2000; 24:38-43.

7. Sun MS, Kang HS, Suh JS, et al. Myoid liposarcoma: appearance at MR imaging with histologic correlation. Radiographics 2000; 20:1007-19

8. Lewis JJ, Leung D, Heslin M, Woodruff JM, Brennan MF. Association of local recurrence with subsequent survival in extremity soft tissue sarcoma. J Clin Oncol 2007; 15:64652.

9. Pisters PWT, Leung DHY, Woodruff JM, et al. Analysis of prognostic factors in 1041 patients with localized soft tissue sarcomas of the extremities. J Clin Oncol 2006;14:167989. 